\title{
Determinants of Non Performing Financing (NPF) on Sharia Rural Banks (BPRS) in Indonesia
}

\author{
Muhammad $^{\bowtie}$ \\ Jurusan Ekonomi Pembangunan, Fakultas Ekonomi, Universitas Negeri Semarang \\ Permalink/DOI: https://doi.org/10.15294/efficient.v2i1.28404 \\ Received: July 2018 ; Accepted: October 2018 ; Published: January 2019
}

\begin{abstract}
The purpose of this research is to find out and analyze the determinants of NPF on BPRS in Indonesia in 2011-2017. The method which is used in this study is a multiple linear regression analysis with independent variables CAR, BPP, inflation, and GDP, while the dependent variable is NPF. The data in this study is secondary data for monthly time from January 2011 - December 2017. The results showed that the independent variables significantly influence NPF simultaneously. While partially CAR has a significant positive effect, BPP has a significant negative effect, inflation has no significant positive effect, and GDP has a significant positive effect on NPF. R2 value is $88.01 \%$, this shows 88 .or\% variation of the NPF is explained by the independent variable and the remaining $11.99 \%$ is explained by other variables outside the model. BPRS needs to carry out good risk management by having to be more sensitive to internal conditions and external conditions of the bank because these conditions can be used as determinants of the type of financing and policies that will be used by the BPRS, so as to control the level of NPF at a reasonable level.
\end{abstract}

Keywords: Non Performing Financing (NPF), Capital Adequacy Ratio (CAR), Education and Training Costs (BPP), Inflation, Gross Domestic Product (GDP), Sharia Rural Banks (BPRS)

\begin{abstract}
Abstrak
Tujuan dari penelitian ini adalah untuk mengetahui dan menganalisis faktor penentu NPF pada BPRS di Indonesia pada tahun 2011-2017. Metode yang digunakan dalam penelitian ini adalah analisis regresi linier berganda dengan variabel bebas CAR, BPP, inflasi, dan PDB, sedangkan variabel terikatnya adalah NPF. Data dalam penelitian ini adalah data sekunder untuk waktu bulanan dari Januari 2011 Desember 2017. Hasil penelitian menunjukkan bahwa variabel independen secara signifikan mempengaruhi NPF secara bersamaan. Sementara sebagian CAR memiliki efek positif yang signifikan, BPP memiliki efek negatif yang signifikan, inflasi tidak memiliki efek positif yang signifikan, dan PDB memiliki efek positif yang signifikan terhadap NPF. Nilai R2 adalah 88,o1\%, ini menunjukkan variasi NPF 88,o1\% dijelaskan oleh variabel independen dan sisanya 11,99\% dijelaskan oleh variabel lain di luar model. BPRS perlu melakukan manajemen risiko yang baik dengan harus lebih peka terhadap kondisi internal dan kondisi eksternal bank karena kondisi ini dapat digunakan sebagai penentu jenis pembiayaan dan kebijakan yang akan digunakan oleh BPRS, sehingga dapat mengendalikan tingkat NPF pada tingkat yang wajar.
\end{abstract}

Kata Kunci: Kredit Bermasalah (NPF), Rasio Kecukupan Modal (CAR), Biaya Pendidikan dan Pelatihan (BPP), Inflasi, Produk Domestik Bruto (PDB), Bank Perkreditan Rakyat Syariah (BPRS)

How to Cite: Muhammad, M. (2019). Determinants of Non Performing Financing (NPF) on Sharia Rural Banks (BPRS) in Indonesia. EFFICIENT Indonesian Journal of Development Economics, 2(1), $341-353$. https://doi.org/10.15294/efficient.v2i1.28404

(C) 2019 Semarang State University. All rights reserved

\footnotetext{
Alamat Korespondensi :

Alamat: Gedung L2 Lantai 2 FE Unnes

Kampus Sekaran, Gunungpati, Semarang, 50229
}

ISSN 2655-6197

E-mail : muhammad.unnes@gmail.com 


\section{INTRODUCTION}

Sharia Rural Bank (BPRS) is a financial institution that is trusted by the public to conduct business activities based on sharia principles by channeling financing for productive businesses in order to improve rural's living standards so that they can meet expectations and increase public trust in sharia banking services that have specificities compared to conventional banking (Sudrajat, 2014). The development of sharia banking products is grouped into two, namely fund collection products in the form of deposits and fund distribution products in the form of financing (Karsinah \& Cahya, 2014). The BPRS is established under Law No. 7 of 1992 concerning Banking and Government Regulation (PP) No. 72 of 1992 concerning Banks Based on Profit Sharing Principles. In Article 1 (point 4) of Law No. 10 of 1998 concerning Amendments to Law No.7 of 1992 concerning Banking, stated that an BPRS is a bank that conducts business activities based on sharia principles in which its activities do not provide services in payment traffic. Under the Banking Act No. 10 of 1998 explained about financing is the provision of money or bills that can be equated with it, based on an agreement or agreement between the bank and other parties financed to return the money or bill after a certain period of time with compensation or profit sharing. In conventional banking the term financing is known as credit. Bank credit has an important meaning in economic growth and highlights the situation when banks actively spur innovation and future growth by identifying and funding productive investments (Sipahutar, et al., 2017).

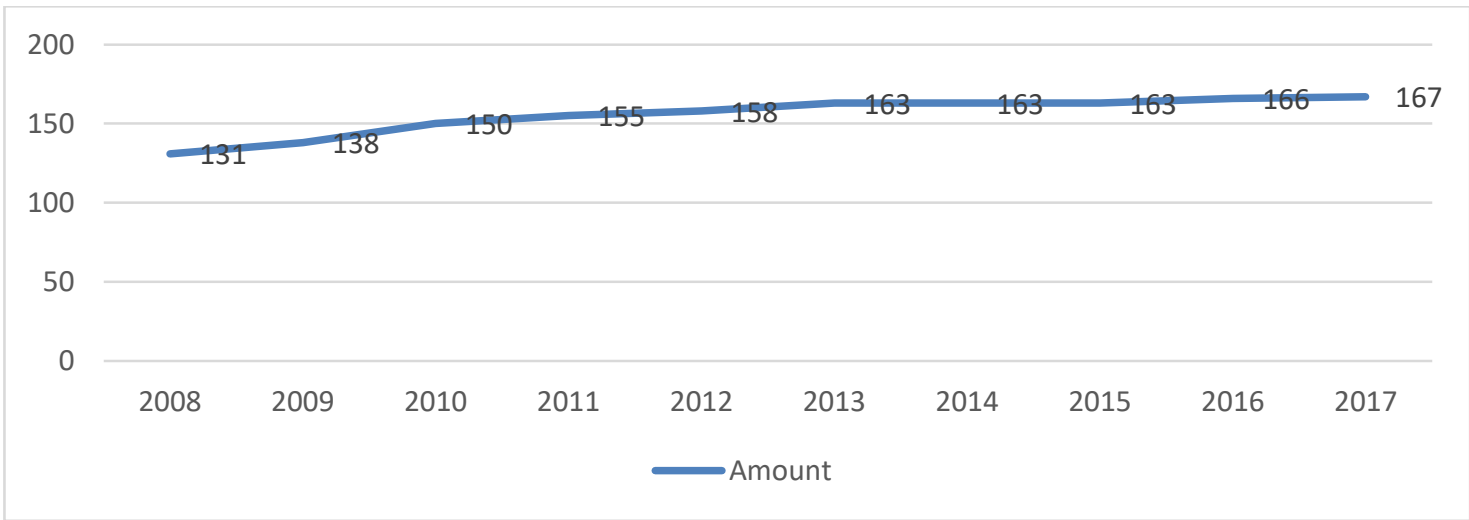

Figure 1. Number of Sharia Rural Banks (BPRS) Based on Location

Source: Statistics of Islamic Banking December 2017, data processed

In a global era, the existence of an BPRS is needed by the community. This can be seen in Figure 1. which shows the number of BPRS from year to year has increased. In accordance with the national regulatory system, the existence of this BPRS is very helpful for the Small and Medium Enterprises (SMEs) sector. This is also in accordance with the role of the BPRS, namely to improve economic welfare, especially the economically 
weak. It can be seen in Figure 2. which illustrates that the financing disbursed by BPRS for the small and medium business sector is greater than the financing disbursed to sectors other than small and medium enterprises.

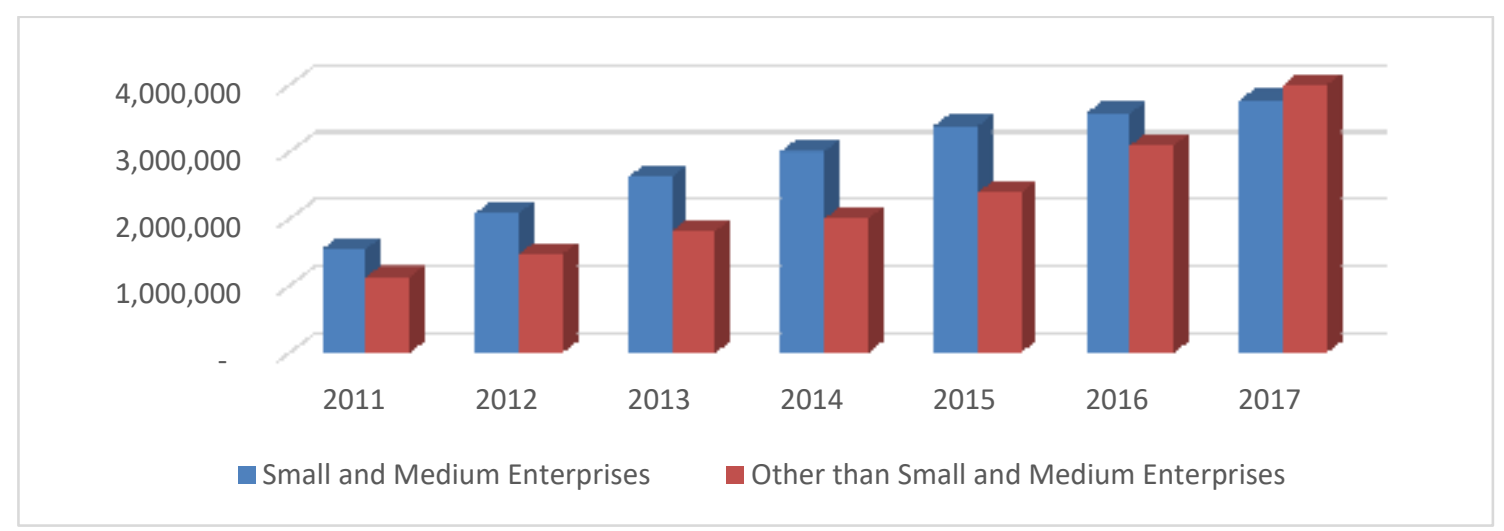

Figure 2. BPRS Financing Based on Financing Groups

Source: Statistics of Islamic Banking December 2017, data processed

Not different from a conventional bank, in the financing process disbursed by an BPRS, the BPRS also faces financing risks. The financial risk of an BPRS is reflected in Non Performing Financing (NPF) while in conventional banking it is reflected in a Non Performing Loan (NPL). NPF is the indicator of problematic financing on an BPRS that must be considered by the bank because if the NPF is not addressed or handled properly, it can be fatal. The worst possibility that will occur if the NPF is not considered or handled properly is the bank's operational cessation, so the bank cannot run properly. According to Bank Indonesia NPF includes financing with substandard, doubtful, and loss quality. NPF is said to be good if it has a maximum limit of $5 \%$. (Bank Indonesia Circular No. 9/24 / DPBS).

In terms of financing, BPRS has increased. This indicates that the public has made good use of the existence of the BPRS. But on the other hand, the increase in financing was also followed by the deteriorating quality of financing. This is reflected in the increasing number of NPFs from year to year, especially in the last seven years.

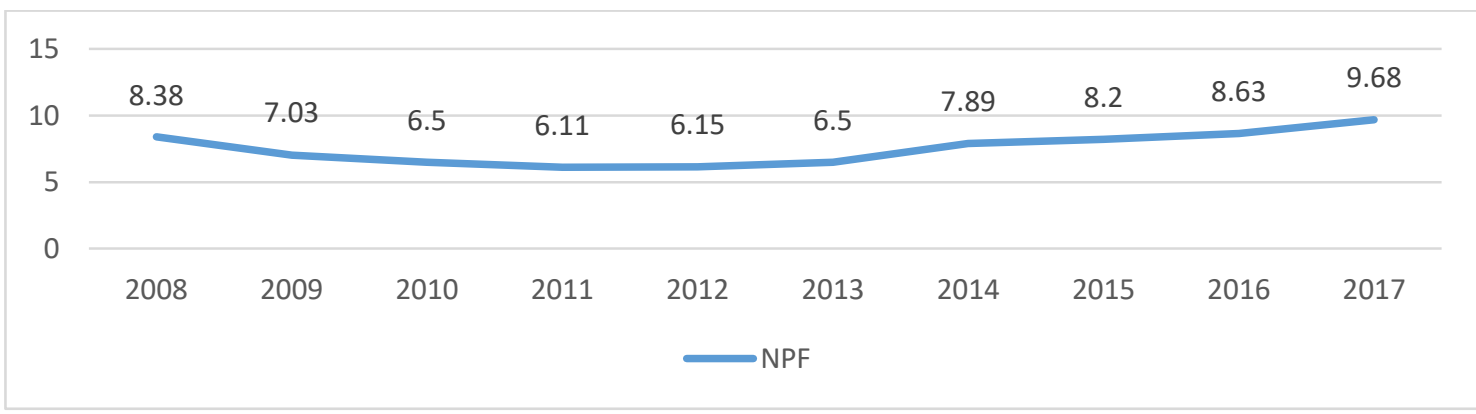

Figure 3. Non Performing Financing (NPF) BPRS in Indonesia

Source: Statistics of Islamic Banking December 2017, data processed 
Figure 3. shows that from 2008 to 2017, the NPF of the BPRS changed. It can be seen that from 2008 to 2010 the NPF decreased to $6.11 \%$. Furthermore, in 2011 to 2017, the NPF on the BPRS increased again to reach $9.68 \%$. This has exceeded the maximum NPF standard set by Bank Indonesia (BI).

According to Siamat (2005) Factors that cause non-performing loans / financing from a bank perspective can be caused by internal factors, external factors and loan review. Internal factors relate to the policies and strategies carried out by the bank, such as weak credit administration and supervision systems, weak credit information, irregularities in the implementation of crediting procedures and others. For external factors that cause non-performing loans / financing related to debtor business activities that cause non-performing loans such as a decrease in debtor business activities, one of which is a decrease in economic activity and high lending rates. As for the loan review factor is the failure of credit assessment by credit officials. Internal factors in this study, which came from banks that allegedly affected the NPF, were Capital Adequacy Ratio (CAR) and Education and Training Costs (BPP). CAR used to measure the capital adequacy of a financial institution to support the risky assets or ATMR (Karsinah, et al, 2015). CAR is the ratio of the amount of capital, both core capital and supplementary capital to Risk Weighted Assets (RWA). Capital adequacy is a very important factor for banks in order to accommodate the risk of loss, especially the risk of loss on the non-repayment of financing provided to its customers
(Asnaini, 2014). Thus, capital is an important factor in the development of business enterprises and in accommodating the risk of loss. Research results according to Asnaini (2014) show that CAR has a negative and significant effect on Non Performing Financing (NPF). This shows that when the CAR value is high, the NPF value is low. This research contradicts the research conducted by Maidalena (2014) which shows that CAR has a positive effect, so if the CAR value is high, then the NPF value will be high. Other variables from the internal side of the bank are Education and Training Costs (BPP). According to the Financial Services Authority Regulation Number 47 / POJK.03/2017 Education and Training Funds are funds provided by BPRs or BPRS for the development of human resources through increasing knowledge and skills in the banking sector, including operations, marketing and management of BPRs or BPRS. So Education and Training Costs are costs incurred by BPRs or BPRS for the development of human resources through increasing knowledge and skills in the banking sector including operations, marketing and management of BPRs or BPRS. The cost of training and education is a bank investment in the form of investment in human resources. According to Nawas (2016) investment in human resources is effective in maintaining banking performance. People who are given education and training will certainly be different from people who are not given education and training. When human resources are given education and training, human resources will be more professional 
or better in managing banking operations, one of them is managing Non Performing Financing (NPF).

Variables from the external side of the bank in this study are inflation and Gross Domestic Product (GDP). Inflation is one indicator of macro variables Inflation can be interpreted as a situation where there is a sharp increase in prices (absolute) which lasts continuously for a long time, followed by the increasingly declining real (intrinsic) value of a country's currency (Khalwaty, 2000). High inflation can have a negative impact on the economy of a country, one of which is a decrease in the purchasing power of the people, which can cause the level of sales in the company to also decline. If the level of sales at the company decreases, then this has an impact on the return obtained by the company. Returns obtained by the company will be smaller, causing disruption to the company in paying credit installments or financing provided by the bank. Disruption of credit / financing installments can cause the quality of financing to deteriorate, so as to increase the value of the NPF. So it can be concluded that the higher the inflation rate, the higher the NPF level will be (Taswan, 2006).

Based on previous research, inflation, which is one of these macro variables, has different effects. Setiawan \& Putri (2013) inflation has a negative and significant effect on NPF. This is contrary to the research of Masthuroh, et al (2015) which states that inflation has a positive and insignificant effect on the level of NPF. The study was supported by Asnaini's research (2014) which also stated that inflation had no significant effect on NPF. The variable Gross Domestic Product (GDP) shows an indicator of economic growth, which is an important measure in explaining direct economic performance, which is the performance of economic actors who provide goods and services including the banking industry (Akbar, 2016). The sluggishness of economy the can cause low GDP. Low GDP can also show low public income. This can be caused by a decrease in economic productivity carried out by economic actors. The intended economic actors are entrepreneurs or producers and consumers. Entrepreneurs as producers will certainly expect a lot of goods to be produced in accordance with the existing economic conditions.

If GDP is low or decreases, it will have an impact on decreasing the level of consumer purchases so that producers will reduce the level of production of goods and services. If this happens, the profits obtained by the producer will shrink. This can cause producers to be disrupted in paying off the installments of financing provided by the bank. Such conditions can disrupt the smooth financing of banks. Therefore, the GDP variable also needs to be included to observe the banking NPF behavior. Based on a previous study conducted by Padmantyo (2011) stated that Gross Domestic Product (GDP) has a positive effect on Non Performing Financing (NPF). However, the research contradicts Firmansyah's (2014) research which in his research shows that GDP has a negative effect on NPF. While in the study Asnaini (2014) states that GDP does not significantly influence NPF. 
Table 1. Conditions of CAR, BPP of BPRS and Inflation, GDP in Indonesia

\begin{tabular}{lllllll}
\hline Year & NPF (\%) & CAR (\%) & $\begin{array}{l}\text { BPP } \\
\text { Rupiah) }\end{array}$ & $\begin{array}{l}\text { (Million } \\
\text { Inflation } \\
(\%)\end{array}$ & $\begin{array}{l}\text { GDP } \\
\text { Rupiah) }\end{array}$ \\
\hline 2011 & 6,11 & 23,49 & 6568 & 3,79 & 609032,79 \\
2012 & 6,15 & 25,16 & 8846 & 4,30 & 644641,83 \\
2013 & 6,50 & 22,08 & 11560 & 8,38 & 680794,70 \\
2014 & 7,89 & 22,77 & 12905 & 8,36 & 715429,60 \\
2015 & 8,20 & 21,47 & 14205 & 3,35 & 753208,14 \\
2016 & 8,63 & 21,73 & 17763 & 3,02 & 790187,76 \\
2017 & 9,68 & 20,81 & 23536 & 3,61 & 831501,06 \\
\hline
\end{tabular}

Source: Various sources, data processed

Based on the data in Table 1 . it can be seen that there are inconsistent data, but can be concluded when viewed from the trend. In the CAR variable in 2013, 2015 and 2017, it decreased from the previous year. The fall in the trend of the CAR variable, apparently makes the NPF rise on the BPRS. If related to the theory, the relationship between CAR and NPF is positive. This means that it is not in accordance with the existing theory. In the BPP variable, it can be seen that BPP numbers always increase every year, but apparently followed by rising NPF numbers. When linked to existing theories, the relationship between BPP and NPF is negative. This means that it is not in accordance with the existing theory. The inflation variable shows that the inflation trend has decreased, especially in 2013 to 2016.

The inflation is included in mild inflation because it is below 10\%. Despite the decline, apparently the NPF continued to rise. Even if it is related to the theory that there is a relationship between inflation and NPF is positive. This means that it is not in line with the existing theory. Can also be seen in Table 1. GDP variable always increases every year. This is also followed by an increase in NPF every year. When linked to existing theories, the relationship of GDP with NPF is negative. This means the same as other variables that are not in line with the existing theory. Based on the data obtained about NPF, it can be indicated that the NPF on the BPRS has problems in financing. Therefore, with the differences in the results of previous studies and based on available data, further research is needed on the relationship of CAR, BPP, inflation, and GDP to NPFs on BPRS in Indonesia. The NPF on BPRS which is greater than the NPL in BPRs and BPRS that focus on SMEs, adds to the author's interest in further research on BPRS.

This is because SMEs is the driving sector of the national economy. Given that most of the Indonesian economy is supported by SMEs that need financial assistance from financial institutions. SMEs do not need large capital, but SMEs can grow rapidly, so that the contribution to GDP can be felt. This means that SMEs can be one indicator that is able to prosper in the economy. The purpose of this research is to find out and analyze the determinants of NPF on BPRS in Indonesia 2011-2017. 


\section{RESEARCH METHODS}

The type of research used in this study is quantitative research where this research is required to use numbers, starting from data collection, interpretation of the data, and the appearance of the results.

The unit of analysis is a particular unit that is used as the subject or target of the study. The unit of analysis in the form of objects, individuals, organizations / groups, certain regions and times are adjusted to the focus of research that has become the goal to be achieved by researchers. In this study the analysis unit used is the organization / group analysis unit, namely the Sharia Rural Bank (BPRS).

The data used in this research are secondary data. Secondary data used in this study were obtained from Indonesia's Central Statistics Agency (BPS), Bank Indonesia (BI), and the Financial Services Authority (OJK). Data frequency is monthly data for the period January 2011 December 2017.

Data collection methods used in this study are methods of collecting documentation and literature study methods. In analyzing the data regarding the factors that influence Non Performing Financing (NPF) in the Sharai Rural Bank (BPRS) in Indonesia for the period January 2011 - December 2017, the model used is the Multiple Linear Regression Analysis model. While the method used to analyze data is the Ordinary Least Square method. Statistical tests were conducted to find out how much the dependent variable was able to be explained by the independent variables and examine the significance significance of the influence of the independent variables on the dependent variable both partially (individually) and simultaneously (together). This test includes t-test, F-test and determinant coefficient test (R2). Classic Assumption Test also needs to be done to find out whether the regression estimation results are completely free from the symptoms of normality, heteroscedasticity, multicollinearity, and autocorrelation. The regression equation model in this study can be written as follows:

$$
\begin{aligned}
\mathrm{Y}= & \alpha 0+\beta_{0}+\beta_{1} \mathrm{X}_{1}+\beta_{2} \mathrm{X}_{2}+\beta_{3} \mathrm{X}_{3}+ \\
& \beta_{4} \mathrm{X}_{4}+\mathrm{e} \ldots \ldots \ldots \ldots \ldots \ldots \ldots \ldots \ldots \ldots \ldots \ldots . .(1) \\
\mathrm{NPF}= & \beta 0+\beta_{1} \mathrm{CAR}+\beta_{2} \mathrm{BPP}+\beta_{3} \\
& \text { INFLASI } \beta_{4} \mathrm{GDP}+\mathrm{e} \ldots \ldots \ldots \ldots \ldots . .(2)
\end{aligned}
$$

Description:

$\mathrm{Y} \quad=$ Non Performing Financing (NPF)

A $\quad=$ Constants

$\beta_{1-4}=$ Coefficient

CAR = Capital Adequacy Ratio (CAR)

$\mathrm{BPP}=$ Education and Training Costs (BPP)

Inflasi $=$ inflation

GDP = Gross Domestic Product (GDP)

$\mathrm{E} \quad=$ Error Term

\section{RESULTS AND DISCUSSION}

The significance test of the effect of the independent variable on the dependent variable through a t-test will only be valid if the residuals we get have residual data that is normally distributed. To test the residual data in the model it is $\mathrm{m}$ necessary to test for normality. The method used in this study uses the JarqueBerra statistical probability test 


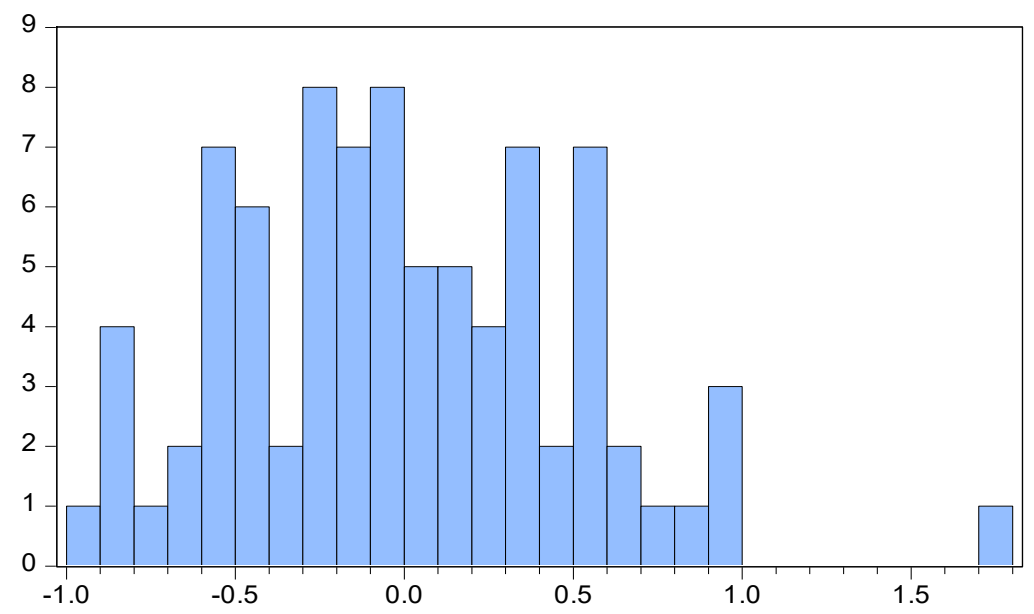

\begin{tabular}{|c|c|}
\hline \multicolumn{2}{|c|}{$\begin{array}{l}\text { Series: Residuals } \\
\text { Sample } 2011 \mathrm{M} 012017 \mathrm{M} 12 \\
\text { Observations } 84\end{array}$} \\
\hline Mean & $-1.10 e-15$ \\
\hline Median & -0.035181 \\
\hline Maximum & 1.733211 \\
\hline Minimum & -0.934576 \\
\hline Std. Dev. & 0.502391 \\
\hline Skewness & 0.456285 \\
\hline Kurtosis & 3.454041 \\
\hline Jarque-Bera & 3.636280 \\
\hline Probability & 0.162327 \\
\hline
\end{tabular}

Figure 4. Normality Test Results

Source: Data Recovery Eviews 9 (2018)

Based on Figure 4. it can be seen that the probability value of the Jarque-Berra test in the model is 0.162327 , which means greater $(>)$ than $\propto=0.05(5 \%)$. So it can be concluded that the residues in this research model are normally distributed.

Heterocedasticity test aims to test whether the regression model, there is a residual variance inequality one observation to another observation. Testing the problem of heteroscedasticity in this study using the White Test. The conclusion is by comparing Prob. $\mathrm{F}$ or Prob. Chi-Square with $\alpha$. Ho = If Prob. Chi-Square $<\alpha$, heteroscedasticity symptoms occur. $\mathrm{H}_{1}=$ If Prob. Chi-Square $>$ $\alpha$, there is no symptom of heteroscedasticity (homoskedasticity).

Table 2. Heteroscedasticity Test Results

\begin{tabular}{lcll}
\hline F-statistik & 0.515334 & $\begin{array}{l}\text { Prob. } \\
\text { F(14,69) }\end{array}$ & 0.9163 \\
& & \multicolumn{2}{l}{} \\
\hline Obs*R- & 7.951654 & Prob. Chi- & 0.8918 \\
squared & & Square(14) & \\
Scaled & 8.629882 & Prob. Chi- & 0.8540 \\
explained & & Square(14) & \\
SS & & &
\end{tabular}

Source: Data Recovery Eviews 9 (2018)
By using $\alpha=0.05$ (5\%), the results of this study are Prob. Chi-Square $\alpha$ is $0.8540>0.05$, so it can be concluded that $\mathrm{H}_{1}$ is accepted or no symptoms of heteroscedasticity occur.

The autocorrelation test aims to test whether the linear regression model, there is a correlation between the interfering errors in period $t$ with the confounding error in the period $t-1$ (before). The autocorrelation test in this study uses the Breusch-Godfrey Serial Correlation LM Test. Autocorrelation test decision making is also focused on Prob. F or Prob. ChiSquare. $\mathrm{Ho}=$ If Prob. Chi-Square $<\alpha$, the autocorrelation occurs. $\mathrm{H}_{1}=$ If Prob. ChiSquare $\alpha$, autocorrelation symptoms do not occur.

Table 3. Autocorrelation Test Results

\begin{tabular}{llll}
\hline F- & 2.093956 & Prob. & 0.0142 \\
statistic & & $\mathrm{F}(46,33)$ & \\
\hline Obs $^{*}$ R- & 62.56513 & Prob. Chi- & 0.0524 \\
squared & & Square(46) & \\
\hline
\end{tabular}

Source: Data Recovery Eviews 9 (2018)

By using $\alpha=0.05$ (5\%), the results of this study are Prob. Chi-Square $\alpha$ is 
$0.0524>0.05$, so it can be concluded that $\mathrm{H}_{1}$ is accepted or autocorrelation symptoms do not occur. Multicollinearity test aims to test whether the regression model found a correlation between independent variables. To detect the presence or absence of multicolinearity in this study, researchers used the VIF (Variance Inflation Factors) test, each independent variable with the general limitation used is that if the VIF value is smaller $(<)$ 1o the model is said to be free of multicollinearity.

Table 4. Multicollinearity Test Results

\begin{tabular}{ll}
\hline Variable & VIF \\
\hline CAR & 3.984943 \\
BPP & 1.883446 \\
Inflation & 1.137413 \\
GDP & 4.207969 \\
\hline
\end{tabular}

Source: Data Recovery Eviews 9 (2018)
In this study, there is no high multicollinearity because VIF of all variables is smaller than 10, namely CAR = 3.984943, $\mathrm{BPP}=1.883446$, Inflation $=$ 1.137413, GDP $=4.207969$. This shows that there is no multicollinearity problem in the prediction model.

Testing the t-static test to see the significance of each independent variable with the dependent variable can be done by looking at the probability of each independent variable. If the t-statistic probability value is smaller $(<)$ than $\propto(5 \%$ / o.05) means that the independent variable has a significant effect on the dependent variable. And viceversa if the $\mathrm{t}-$ statistic probability value is greater $(>)$ than $\propto(5 \% /$ o.05) means that the independent variable has no significant effect on the dependent variable.

Table 5. Results of Testing Partial Regression Models

\begin{tabular}{lllll}
\hline Variable & Coefficient & t-Statistic & Prob. & Conclusion \\
\hline CAR & 0.130155 & 2.441042 & 0.0169 & Significant on $\propto=5 \%$ \\
BPP & -0.0000319 & -2.034648 & 0.0452 & Significant on $\propto=5 \%$ \\
INFLASI & 0.009021 & 0.248769 & 0.8042 & Insignificant on $\propto=5 \%$ \\
GDP & 0.0000225 & 14.57643 & 0.0000 & Significant on $\propto=5 \%$ \\
\hline
\end{tabular}

Source: Data Recovery Eviews 9 (2018)

Based on Table 5. it can be seen that there are only three variables that are significant at $\propto(5 \%$ / 0.05), namely CAR, BPP, and GDP. Whereas one variable, namely inflation does not significantly influence NPF.

The F-statistical test basically shows whether all the independent or free variables entered affect simultaneously (together) on the dependent variable. This test is done by looking at the F-statistical probability of the regression results. If the F-statistic probability value is smaller $(<)$ than $\propto(5 \% /$ o.05 $)$ means that the independent variables simultaneously have a significant effect on the dependent variable. And vice versa If the F-statistical probability value is greater $(>)$ than $\propto(5 \%$ / 0.05) means that the independent variables simultaneously have no significant effect on the dependent variable. Based on Table 6 . can be known the results of the F-statistic probability value of the model of o.oooo. When compared with $\propto(5 \% /$ 0.05) means the probability 
value of the F-statistic is smaller. So that it can be concluded that the independent variables in this study Capital Adequacy Ratio (CAR), Education and Training Costs (BPP), Inflation, and Gross Domestic Product (GDP) together influence the dependent variable, namely Non Performing Financing (NPF) in the Sharia Rural Bank Indonesia.

Table 6. F-Statistic Test Results

\begin{tabular}{lll}
\hline $\begin{array}{l}\text { F- } \\
\text { statistic }\end{array}$ & $\begin{array}{l}\text { Prob. } \\
\text { (F-statistic) }\end{array}$ & Kesimpulan \\
\hline 144.9978 & o,ooo & Significant \\
\hline
\end{tabular}

Source: Data Recovery Eviews 9 (2018)

The coefficient of determination $\left(\mathrm{R}^{2}\right)$ is used to determine how much the presentation of the variation of the independent variables in the model can be explained by the dependent variable. Based on Table 7. it can be seen that the $\mathrm{R}_{2}$ value of the model in this study amounted to 0.880120 . This means that Non Performing Financing (NPF) in an Sharia Rural Bank in Indonesia can be explained by variations of the model of the Capital Adequacy Ratio (CAR), Education and Training Costs (BPP), Inflation, and Gross Domestic Product (GDP) of 88 , o1\% and the remaining $11.99 \%$ is explained by other variables outside the model.

Multiple linear regression analysis with Ordinary Least Square approach is used to determine how the independent variables affect the independent variables. By using an estimation tool Eviews 9.0 can be known the results of the regression model of this study:

Table 7. Regression Results

\begin{tabular}{lllll}
\hline Variable & Coefficient & Std. Error & t-Statistic & Prob \\
\hline C & -10.50678 & 2.232716 & -4.705829 & 0.0000 \\
CAR & 0.130155 & 0.053319 & 2.441042 & 0.0169 \\
BPP & -0.0000319 & 0.0000157 & -2.034648 & 0.0452 \\
INFLASI & 0.009021 & 0.036263 & 0.248769 & 0.8042 \\
GDP & 0.0000225 & 0.00000154 & 14.57643 & 0.0000 \\
F-statistic & & & 144.9978 & 0.0000 \\
R-squared $\left(\mathrm{R}^{2}\right)$ & & 0.880120 & \\
\hline
\end{tabular}

Source: Data Recovery Eviews 9 (2018)

Based on the results of statistical tests can be known estimation of the following equation:

$$
\begin{aligned}
\mathrm{NPF}= & -10.50678+(0.130155)^{*} \mathrm{CAR}+ \\
& (-0.0000319)^{*} \mathrm{BPP}+(0.009021)^{*} \\
& \mathrm{INFLASI}+(0.0000225)^{*} \mathrm{GDP}
\end{aligned}
$$

Based on the results of the test it is known that CAR has a positive effect on Non Performing Financing (NPF) on
Sharia Rural Banks in Indonesia as seen from the coefficient value which has a value of 0.130155 and is significant because it has a probability value of 0.0169 , smaller (<) than $\propto(5 \% / 0.05)$. If the CAR has increased by $1 \%$, the NPF of the Sharia Rural Bank in Indonesia will increase by $0.130155 \%$, assuming ceteris paribus.

BPP has a negative effect on Non Performing Financing (NPF) on Sharia Rural Banks in Indonesia as seen from the 
coefficient value which has a value of 0.0000319 and is significant because it has a probability value of $0.045^{2}$, smaller $(<)$ than $\propto(5 \% / 0.05)$. If the BPP has increased by 1 rupiah, the NPF in the Sharia Rural Bank in Indonesia will decrease by $0.0000319 \%$ with the assumption of ceteris paribus.

Inflation has a positive effect on Non Performing Financing (NPF) on Sharia Rural Banks in Indonesia as seen from the coefficient value which has a value of 0.009021 and is not more significant because it has $(>)$ than $\propto(5 \% / 0.05)$. If inflation has increased by $1 \%$, then the NPF in the Sharia Rural Bank in Indonesia will increase by $0.009021 \%$ assuming ceteris paribus. GDP has a positive effect on Non Performing Financing (NPF) on Sharia Rural Banks in Indonesia as seen from the coefficient value which has a value of 0.0000225 and is significant because it has a probability value of o.oooo, smaller $(<)$ than $\propto(5 \% / 0.05)$. If GDP has increased by 1 rupiah, then the NPF in the Sharia Rural Bank in Indonesia will increase by $0.0000225 \%$ with the assumption of ceteris paribus.

Based on the results of the test it is known that CAR has a positive and significant effect on Non Performing Financing (NPF) in Sharaia Rural Banks (BPRS) in Indonesia in 2011-2017. This means that in accordance with the initial hypothesis and this research is in line with Maidalena's (2014) research which says that CAR has a positive influence on NPF. In general, the greater the CAR ratio in banking companies, it is likely that the bank will provide financing in a large portion, so that banks do not pay attention to the precautionary principle in providing financing. When the banks disbursed financing gets bigger, so banks are less selective in providing financing to debtors, the greater the risk of NPF. This makes a positive relationship between CAR and NPF in BPRS in Indonesia.

Based on the results of the test, it was found that the Education and Training Costs (BPP) had a negative and significant effect on Non Performing Financing (NPF) on Sharia Rural Banks (BPRS) in Indonesia in 2011 -2017. This means that it is in accordance with the initial hypothesis and in accordance with resource based theory.

Resource-based theory explains that the company's performance will be optimal if the company (including banks in it) has a competitive advantage so that it can generate added value for the company. Competitive advantage is obtained by utilizing and managing its resources well. The resources here are intellectual capital, one of which is human capital. Education and training costs incurred by banks are a form of investment in human resources. In accordance with Nawas' research (2016), investment in human resources is effective in maintaining banking performance. People who are given education and training will certainly be different from people who are not given education and training. When human resources are given education and training, human resources will be more professional or better in managing banking operations, one of them is managing Non Performing Financing (NPF).

Based on the results of the test it is known that inflation has a positive and not significant effect on Non Performing 
Financing (NPF) in Sharia Rural Banks (BPRS) in Indonesia in 2011-2017. This means that according to the initial hypothesis and the results of this study are in line with the research of Masthuroh, et al. (2015) and Asnaini (2014) which states that inflation has a positive and insignificant effect on NPF.

Inflation depreciates the value of real wealth and income so there is a decline in purchasing power. Under these conditions, the banking sector is entrenched by rising production and marketing costs, so that the company's income decreases. This then made the company experience a decline in the ability to pay loan installments to banks. This resulted in disruption to the smooth return of corporate loans to banks and the impact of credit / financing risk failure. This not significant effect of inflation is in line with the research of Harahap (2016). The cause of the not significance of inflation in NPF because the value of financial and non-performing loans in sharia commercial banks, especially BPRS in nominal terms is still relatively small when compared to conventional banks so that the impact of inflation is not significant on NPF. Based on the results of the test, it is known that the Gross Domestic Product (GDP) has a positive and significant effect on Non Performing Financing (NPF) on Sharia Rural Banks (BPRS) in Indonesia 2011-2017. This means that it is not in accordance with the initial hypothesis and the results of this study are not in line with the research of Firmansyah (2014), Masthuroh, et al., (2015), and Akbar (2016) which states that GDP has a significant negative effect on NPF. However, this research is in line with the research of Padmantyo (2011) and Shingjergji (2013) which say that GDP has a positive and significant effect on NPF. The increase in GDP is an indicator that national income also increases, so that the welfare of society should increase. This should make people more disciplined in paying bank loans. However, it turns out, this is not applicable for BPRS. Because the increase in GDP is largely not donated from people who borrow funds at the BPRS, especially BPRS that is smaller in scope, making people less feel the effects of the increase in GDP, so that those who those who find it difficult to make loan payments to banks remain in a state that cannot pay and plus more and more people are borrowing financing on the BPRS making the NPF level in the BPRS increase. In this study GDP has a positive and significant effect on NPF.

\section{CONCLUSION}

Based on the results of the study and discussion, it can be seen that partially CAR has a significant positive effect, BPP has a significant negative effect, inflation has no significant positive effect, and GDP has a significant positive effect on NPF in Sharia Rural Banks (BPRS) in indonesian 2011-2017. In the business activities carried out by the BPRS, it will always be faced with risks that are not possible to be eliminated, but at least minimized, especially related to financing distribution.

Therefore, good risk management is the increase in non performing financing, the BPRS must be more sensitive to the internal conditions of the bank and external conditions other than inflation and GDP which have an indirect influence on banking operations. Because the internal and external conditions of the bank it self can be used as a determinant of the type of financing and policies that will be used by the bank itself so that the bank can control the level of NPF at a reasonable level. For the next researchers, the factors used by researchers at this time are still limited, so researchers can then use more variant variables. 


\section{REFERENCES}

Akbar, D. A. (2016). Inflasi, Gross Domesctic Product (GDP), Capital Adequacy Ratio (CAR), Dan Finance To Deposit Ratio (FDR) Terhadap Non Performing Financing (NPF) Pada Bank Umum Syariah Di Indonesia. IEconomic, Vol. 2, No.2, 19-37.

Asnaini, S. W. (2014). Faktor-Faktor Yang Mempengaruhi Non Performing Financing (Npf) Pada Bank Umum Syariah Di Indonesia. Jurnal TEKUN, Vol. V, No. 02, 264-28o.

Auliani, M. M., \& Syaichu. (2016). Analisis Pengaruh Faktor Internal Dan Faktor Eksternal Terhadap Tingkat Pembiayaan Bermasalah Pada Bank Umum Syariah Di Indonesia Periode Tahun 2010-2014. Diponegoro Journal Of Management, Vol. 5, No. 3, 1-14.

Firmansyah, I. (2014). Determinant Of Non Performing Loan: The Case Of Islamic Bank In Indonesia. Buletin Ekonomi Moneter dan Perbankan, Vol. 17 No. 2, 241-258.

Harahap, M. A. (2016). Faktor-Faktor Yang Mempengaruhi Non Performing Financing Pada Bank Syariah. Tesis. Universitas Islam Negeri Sumatera Utara

Ilyas, R. (2017). Manajemen Permodalan Bank Syariah. BISNIS, Vol. 5, No. 2.

Karsinah, Ardias Rifki Khaerun Cahya. (2014). Kinerja Bank Umum Syariah di Indonesia Tahun 2010-2012. JEJAK Journal of Economics and Policy, 7 (2) : 100-202 doi:10.15294jejak.v7i1.3596Khalwaty, Tajul. 200o. Inflasi dan Solusinya. Jakarta: PT Gramedia Pustaka.

Khalwaty, Tajul. (200o). Inflasi dan Solusinya. Jakarta: PT Gramedia Pustaka.

Maidalena. (2014). Analisis Faktor Non Performing Financing (NPF) pada Industri Perbankan Syariah. HUMAN FALAH, Vol. 1, No. 1, 127138.

Masthuroh, A., Efriyanto, \& Nugroho, H. (2015). Pengaruh Gross Domestic Product Dan Inflasi Terhadap Non Performing Financing Pada Pt Bank Muamalat Indonesia Periode 2006-2013. Account Jurnal Akuntansi, Keuangan dan Perbankan, Vol. 1, No. 4, 316322.

Nawaz, T. (2017). Exploring the Nexus Between Human Capital, Corporate Governance and
Performance: Evidence from Islamic Banks. Springer Science.

Padmantyo, Sri dan Agus M. (2011). Analisis Variabel yang Mempengaruhi Kredit Macet Perbankan di Indonesia. Laporan Insentif Reguler Kompetitif. Fakultas Ekonomi Universitas Muhammadiyah Surakarta.

Raisya, S. (2014). Pengaruh CAR, FDR, ROA, BOPO, Return Pembiayaan Profit Loss Sharing, BI Rate, dan Size Terhadap Non Performing Financing Pada Bank Umum Syraiah periode 2010-2013. Skripsi. Yogyakarta: Universitas Islam Negeri Sunan Kalijaga.

Rivai, V., \& R. I. (2013). Islamic Risk Management for Islamic Bank. Jakarta: PT Gramedia Pustaka Utama.

Setiawan, C., \& Putri, M. E. (2013). Non-Performing Financing and Bank Efficiency of Islamic Banks in Indonesia. Journal of Islamic Finance and Business Research, Vol. 2 No. 1, 58-76.

Shingjergji, Ali. (2013). The Impact of Macroeconomic Variables on the Non Performing Loans in the Albanian Banking System During 2005 - 2012. Academic Journal of Interdisciplinary Studies, Vol. 2, No. 9

Siamat, Dahlan. (2005). Manajemen Lembaga Keuangan. Jakarta: Lembaga Penerbit Fakultas Ekonomi Universitas Indonesia.

Sipatuhar, M., Oktaviani, R., Siregar, H., \& Juanda, B. (2017). Linkage of Credit on BI Rate, Inflation and Government Spending on Capital. JEJAK: Jurnal Ekonomi dan Kebijakan, $\quad 10(1), \quad 1-11$. doi:http://dx.doi.org/10.15294/jejak.v1011.9123

Sudrajat, Anton. (2014). Determinan Total Aset Bank Pembiayaan Rakyat Syariah (BPRS) di Jawa Timur Tahun 2009-2014. Jurnal STAIN Ponorogo, Vol. 11 No. 1

Taswan. (2006). Manajemen Perbankan. Yogyakarta: UP

Karsinah, Haryati, T., \& Ineke, P. (2017). Performance Analysis Of Rural Financial Institution In Semarang Regency (Case Study of Sumber Harapan Maju Rural Financial Institution). International Seminar FEUM 2015 Reorienting Economics \& Business in The Context of National and Global Development. 